\title{
Transcription Factor NF-E2 45 kDa Subunit
}

National Cancer Institute

\section{Source}

National Cancer Institute. Transcription Factor NF-E2 45 kDa Subunit. NCI Thesaurus.

Code C93118.

Transcription factor NF-E2 $45 \mathrm{kDa}$ subunit (373 aa, $41 \mathrm{kDa}$ ) is encoded by the human NFE2 gene. This protein plays a role in the regulation of gene expression during blood cell maturation. 